Insights into the dubbing process: a genetic analysis of the Spanish dubbed version of Ocean's Eleven

\title{
Rocío Baños
}

Centre for Translation Studies, University College London, London, UK

r.banos@ucl.ac.uk

Rocío Baños is Associate Professor in Translation at the Centre for Translation Studies at University College London, where she teaches Audiovisual Translation and Translation Technology. She holds a PhD on dubbing from the University of Granada. Her main research interests lie in the fields of Audiovisual Translation, Translation Technology and Translation Training. She has published various papers in these areas. Her latest research has focused on 'lesser forms' of audiovisual translation, in particular on the voiceover translation of reality TV, fandubbing and fundubbing. 


\title{
Insights into the dubbing process: a genetic analysis of the Spanish dubbed version of Ocean's Eleven
}

\begin{abstract}
This paper sets out to investigate the traces left by the agents involved in the dubbing process in an attempt to shed light onto its dynamics. The aim is to foreground the role of the different dubbing professionals in the forging of the final dubbed text that reaches audiences, with an emphasis on the translator and the dialogue writer. This will be done reflecting on the concept of genetic analysis in dubbing and undertaking such an analysis on the Spanish dubbed version of Ocean's Eleven Scene 12. Three different versions (the translation, the adapted version and the final recorded version) will be analysed and compared to describe their characteristics, identify the types of changes introduced by different agents, and investigate the reasons that might have motivated such shifts. In line with existing studies drawing on genetic analysis, the results indicate that the changes introduced during the different dubbing phases tend towards text reduction and condensation, and are mainly motivated by synchronisation. The analysis has also underscored the collaborative nature of dubbing, which goes beyond collective agency, suggesting that the document provided by translators is indeed preliminary, but not as 'rough' as we might be led to believe.
\end{abstract}

KEYWORDS Dubbing; Dubbing Process; Genetic Analysis; Collaborative Dubbing; Dubbing Conventions; Professional Aspects 


\section{Introduction}

The effectiveness of dubbed programmes is at times assessed by their capacity to make audiences disregard that what they are watching is not an 'original' audiovisual text, but one that has been rewritten, extensively rehearsed, recorded, and brought to life in a different language by a team of professionals. A recent article published in The New York Times highlighted the effort the popular streaming platform Netflix is placing on making their dubbed content sound more spontaneous (Goldsmith 2019, online). The article argues that the dubbing director plays a paramount role in this regard; however, as discussed by scholars investigating dubbing (Chaume, 2012; De los Reyes Lozano, 2016; Matamala, 2010; Richart-Marset, 2013; Spiteri Miggiani, 2019; Zanotti, 2014), the achievement of spontaneous-sounding dialogues, and the whole dubbing process, is a joint effort from a wide range of agents.

When appraising the Italian dubbed version of Shrek, Minutella (2015, p. 156) posits that its high quality "is the result of a collaborative rewriting process that starts with a good, detailed, dialogue list which is translated by a highly qualified professional and is then reworked and given new life by the dialogue writer". While the role of translators may be overlooked, especially when dubbing is portrayed in the media ${ }^{1}$, or considered inferior compared to that of dialogue writers (Paulínyová, 2016, p. 13), they are responsible for jump-starting the dubbing process by providing a translation of the original audiovisual text. Once translated, the script is adapted and synchronised by the dialogue writer or adapter. Translators might also be responsible for the adaptation and synchronisation of the script and thus be paid for both tasks, yet this varies amongst countries and even within the same country. Especially when different people are in charge of the translation and adaptation, the work carried out by the translator is 
sometimes referred to as a draft or "rough translation" (Whitman-Linsen, 1992, p. 105), that is, "a literal translation which reflects all the idiosyncrasies of the source text and culture" (Chaume, 2012, p. 29) and which undergoes many changes during the adaptation process.

Dialogue writing involves adapting the translated script to the articulatory movements of the on-screen characters, ensuring that the translation respects phonetic synchrony, that is, the open vowels and bilabial and labiodental consonants uttered in shots where characters' faces are clearly visible (Chaume, 2012, p. 73). Adapters are also responsible for making sure that the duration of the translation is identical to that of on-screen characters' utterances (a type of synchrony referred to as isochrony), and observe "kinesic synchrony", by which the translation should be synchronised with the actors' body movements (Chaume, 2012, p. 70). Dialogue writing can also involve dividing the text into dubbing units (takes) and inserting dubbing symbols to ease the interpretation of the adapted dialogue by voice talents.

Dubbing actors are recruited and supervised by the dubbing director and interpret the adapted dialogue in the dubbing booth. They tend to do so individually, even when sharing scenes with other actors (Spiteri Miggiani, 2019, p. 12), following the division of the text into takes in the recording, which is then reassembled and edited by sound engineers. Although there are variations, this is the process usually followed in Spain, where all stages "involve manipulation to some extent of the text submitted by the translator" (Martínez, 2004, p. 5), and other countries operate in a similar way. Collective agency is not exclusive to dubbing. Original audiovisual texts (films, TV series, cut scenes in videogames, etc.) also involve scriptwriters, directors and actors, among others (see Messerli, this volume); however, the concept of authorship is further blurred in dubbed texts. While the dynamics of collaborative writing in other 
contexts can be transparent or at least traceable (e.g. the writing of Wikipedia articles), this is not the case in dubbing. Yet, unveiling such dynamics could be of great interest to both the dubbing industry and academia. Against this backdrop, this paper sets out to investigate precisely what viewers are not supposed to notice, what is supposed to remain uncovered - the "dubbing black box" (Richart-Marset, 2013), or the traces left by the agents involved in the dubbing process -, in an attempt to shed light onto the dynamics of dubbing. It also aims to explore the nature of the collaboration between different dubbing agents further. This is of relevance considering that, while researchers refer to dubbing as collaborative (see above), the descriptions of workflows available in the existing literature (Chaume, 2012, p. 31; Martínez, 2004) portray dubbing not as a truly collaborative task where professionals work together, but as a compartmentalised activity consisting of several one-way processes, where changes are made without consulting each other.

The aim is to undertake a 'genetic analysis' of the Spanish dubbed version of the scene analysed in this special issue (Ocean's Eleven Scene 12). As Zanotti (2014, p. 117) explains, such an analysis relies in 'genetic criticism', a discipline of textual scholarship that aims to reconstruct the process by which a particular text came into being. Genetic analysis thus involves retrieving, studying, describing and interpreting textual traces and archival material (Richart-Marset, 2013, p. 53) to draw conclusions on the dubbing product and also on its process, paying attention to the interaction between agents. This will be done in an attempt to give dubbing professionals 'a voice' in this volume and to bridge the gap between academia and professional practices.

In addressing Ocean's Eleven scene as a source of cogitation on the dubbing process, this paper underlines the limitations of the sample data provided for the understanding of the challenges this scene presents as regards its dubbing into Spanish, 
inasmuch as it only reveals the final result of a laborious process. This approach follows Richart-Marset's line of argument and contention that the study of dubbed versions focusing exclusively on their "most accessible textual surface" (2013, p. 52, my translation), i.e. the final version reaching target viewers, is insufficient. The reasons underlying this assertion will be further explained below, when exploring the concept of genetic analysis in dubbing. This discussion will be followed by the genetic analysis of Ocean's Eleven Scene 12, with a comparison between the different textual surfaces retrieved to reconstruct the steps taken to dub this scene: the translation, the adapted version and the final recorded version.

\section{The role of genetic analysis in the study of dubbed textual production}

Although the undertaking of archival research in the study of translation as a product and as a process is not unheard of in translation studies, archival documents are still widely underutilised in our discipline (Munday, 2013). The potential of drafts, manuscripts and archives to provide "unrivalled insight into translator decision-making" (Munday, 2013, p. 125) is not exclusive to literary translation, and there have been extremely insightful studies undertaken within audiovisual translation (AVT) as well. Archival material has enabled AVT scholars to investigate the ideological manipulation of dialogue in a variety of contexts, especially those illustrating the use of dubbing as a tool to implement censorial practices typical of dictatorial regimes (Díaz-Cintas, 2018; Mereu Keating, 2016). In this particular case, our interest lies in the use of such material to provide a window into the working practice of agents involved in the dubbing process, realised in the studies undertaken by Matamala (2010), Richart-Marset (2013), Zanotti (2014), De los Reyes Lozano (2016) and Paulínyová (2016).

Matamala's (2010) is one of the first studies to investigate the different provisional and final textual sources produced throughout the dubbing of a film and to 
document the changes translations undergo before reaching the target audience.

Focusing on the Spanish dubbing industry and comparing dubbing into Spanish and into Catalan, her findings show that the most frequently implemented strategy throughout the different stages of the dubbing process involves text reduction, followed by amplification (Matamala, 2010, p. 113). Her study exposes the constant tweaking these textual surfaces are subject to, with dialogue writers and actors regularly adding and removing information to comply with synchrony constraints.

In this vein, the genetic analysis model suggested by Richart-Marset (2013) highlights the need to take into consideration a wide range or factors in the analysis of dubbed products. She argues that the analysis of dubbed versions cannot solely delve into how a particular term or expression has been translated, but that it should also investigate the reasoning behind the translation decision-making process. The model she proposes is clearly evaluative, and contends that genetic analysis is by necessity of an ideological nature, with ideologemes revealed in the textual traces left by the agents involved in the dubbing process (Richart-Marset, 2013, p. 60). In addition, her conception of the rough translation as "precarious translation" (Richart-Marset, 2013, p. 57, my translation) underscores the provisional and preliminary nature of the work carried out by the translator and, in my view, even its inferior status. Paulínyová (2016, p. 13) seems to concur, arguing that the inferior or auxiliary role attributed to dubbing translators, compared to dialogue writers, results in lower financial compensation and lack of recognition (see also Cadena Ser, 2019).

This "precarious translation" is nevertheless essential for the reconstruction of the creative process undertaken in dubbing, as are the rest of the documents that precede the final dubbed version. Compiling all these working documents can be an arduous task, involving tracking down unpublished texts (not necessarily available in archives), 
contacting various professionals and relying on their agreement to share material with researchers (De los Reyes Lozano, 2016, p. 151). Yet this is the only way to ascertain the involvement of the different agents in each stage of the dubbing process and to unveil the dialogue established amongst them.

Following Richart-Marset's model, the study undertaken by De los Reyes Lozano (2016) focuses on the dialogic mechanisms used by the translator of the animated film Rio (Carlos Saldanha, 2011) from English into Spanish, to communicate with the dialogue writer. These include translators' notes, alternative solutions, amplifications, questions and dubbing symbols conveying paralinguistic information, all of which are investigated by the author. His findings reveal that the decisions taken by the dialogue writer seem to be clearly motivated by the need to maintain isochrony and lip synchrony, and are also determined by the target audience (children in this case). This is in line with the conclusions reached by Zanotti (2014) in the case study conducted on the Italian dubbing script of the film Young Frankenstein (Mel Brooks, 1974). Zanotti establishes a comparison between the adapted version and the final recording, and reveals that "the text prepared by the dialogue adapter underwent extensive rewriting during the recording process" (Zanotti, 2014, p. 130), with changes motivated by issues relating to synchrony, linguistic characterisation, humour or register. Her findings highlight the authorial role of dubbing directors and dubbing actors and therefore the co-creational nature of dubbing.

Another commonality of most of the studies discussed above is the emphasis they place on the volatile nature of the translated version. While Zanotti (2014, p. 131) argues that "in dubbing the translator may well be left out of the creational part of the process", De los Reyes Lozano (2016) refers to the frailty and malleability of their work. Paulínyová (2016, p. 17) adopts a slightly different standpoint in her genetic 
analysis of the Slovak dubbing of the British TV series Sherlock, as she argues that "a translator can influence the quality of the final product and therefore should [...] not count on the fact that their colleagues will radically change their work". She reaches this conclusion given that, in her study, a substantial amount of the translator's version (42\%) did not undergo any changes. As a result, she contends that the role of translators is not inferior to that of dialogue writers and that they should be seen as equal in the creational dubbing process.

This exploration of the role of genetic criticism in existing dubbing research and the conclusions it has highlighted in relevant studies is taken up in the next section with a genetic analysis of the scene investigated across this special issue. Given this is a short scene, a systematic comparison with existing work is not possible. Nevertheless, the aim is to reveal whether any of the trends summarised above are also present in the sample analysed.

\section{A genetic analysis of the Spanish dubbed version of Ocean's Eleven}

According to the information provided by the database Eldoblaje.com (2019), the dubbing of Ocean's Eleven (Steven Soderbergh, 2001) from English into Spanish was commissioned by Warner Sogefilms to Sonoblok, a dubbing studio in Barcelona. The Spanish version was released in 2002, under the title Ocean's Eleven, and the subtitle Hagan juego ('Place your bets'). Quico Rovira-Beleta was responsible for the translation of this version, while the dialogue writing was undertaken by Gonzalo Abril, who was also appointed dubbing director. Both Rovira-Beleta and Abril are two very well-known professionals in the Spanish dubbing industry, with an extremely prolific trajectory in this sector. Although the former has experience as a dialogue writer, in this case the translation and dialogue writing into Spanish were commissioned to two different individuals, which is common in Spain, especially in filmic productions. 
Both Rovira-Beleta and Abril kindly agreed to provide their working documents corresponding to the scene analysed in this special issue, and answered any questions regarding the dubbing process followed or specific decisions taken. Conversation with these two professionals ${ }^{2}$ revealed that, before being recorded in the dubbing studio, the adapted version was reviewed by a supervisor appointed by the producer. Figure 1 illustrates the process followed for the recording of the scene analysed, with especial emphasis on the textual resources that can shed light onto the decision-making process.

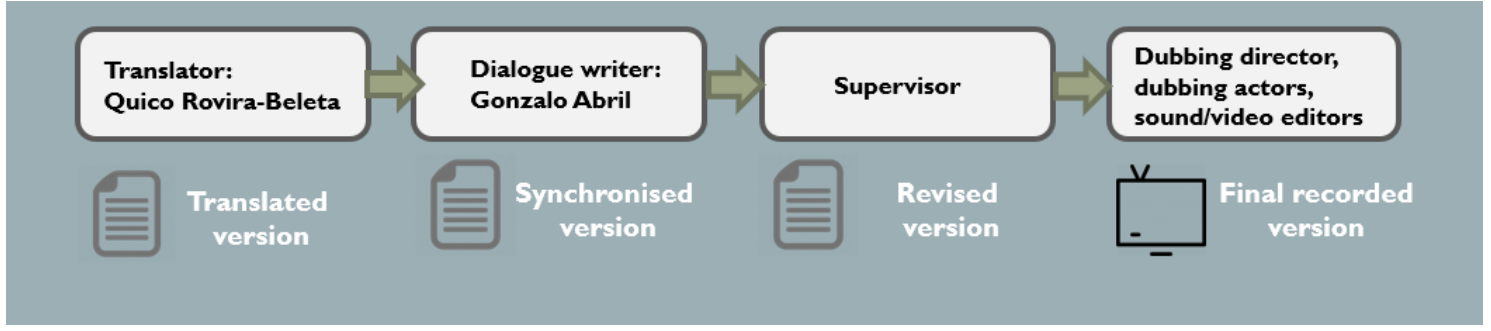

Figure 1. Ocean's Eleven's English to Spanish dubbing process

For the purposes of this article, the following documents were retrieved for analysis and comparison of Scene 12: translated version, synchronised version, and final recorded version. Although it was not possible to retrieve the revised version, the three sources of information gathered suffice to meet the aims of this article:

a) to analyse the working documents to appraise similarities and differences with the conventions used in the dubbing industry;

b) to reconstruct creative processes behind the dubbing of this scene and ascertain the involvement of the different professionals;

c) to analyse the type and volume of changes implemented during each stage and their potential motivation.

The aim is to determine if, as concluded by previous studies, these changes tend 
towards text reduction and condensation (Matamala, 2010) and are mainly motivated by synchronisation (De los Reyes Lozano, 2016). To this end, the analysis will adapt the type of strategies suggested by Matamala (2010) and investigate potential motivations behind the changes. It would also be interesting to find out if changes are more frequent in the dialogue writing stage or during the final recording stage, i.e., implemented by the dubbing director and voice talents (Zanotti, 2014). The analysis of working documents for goal a) will draw on the work carried out by Cerezo Merchán et al. (2016) and their landscaping of the most frequently implemented conventions in the Spanish dubbing industry. To fulfil aims b) and c) any information demonstrating the collaborative and dynamic nature of dubbing will be identified, especially as regards the exchange of opinions between the different participants in the dubbing process and how this exchange is reflected in the textual sources analysed.

The analysis also relies on extratextual information, since the translator and dialogue writer were also contacted to shed further light on unclear results. Given that nearly 20 years have passed since the release of this dubbed version, these professionals might not be able to answer specific questions in detail. This could be deemed another challenge posed by the material analysed.

\subsection{Translated version and synchronised version: overview and comparison}

This section compares the so-called 'rough translation' and the adapted or synchronised version. Particular attention is paid to the dubbing conventions reflected in the working documents analysed and to the dialogic mechanisms used by the translator to communicate with the dialogue writer (see 2.1.1.). The changes implemented in the synchronised version are then analysed, both quantitatively and qualitatively (see 2.1.2). 


\subsubsection{Analysis of information in the translated version}

In terms of macrostructure, the extract of Ocean's Eleven Scene 12 shown in Figure 2

illustrates that the Word file submitted by Rovira-Beleta is divided into reels. The sample focused on, featuring reels 5 and 6, is formatted in Courier New 12 and contains no time codes, as in the rest of the text. Characters names are included in a separate line, preceded by a double slash, while their utterances are included underneath, this time preceded by a single slash.

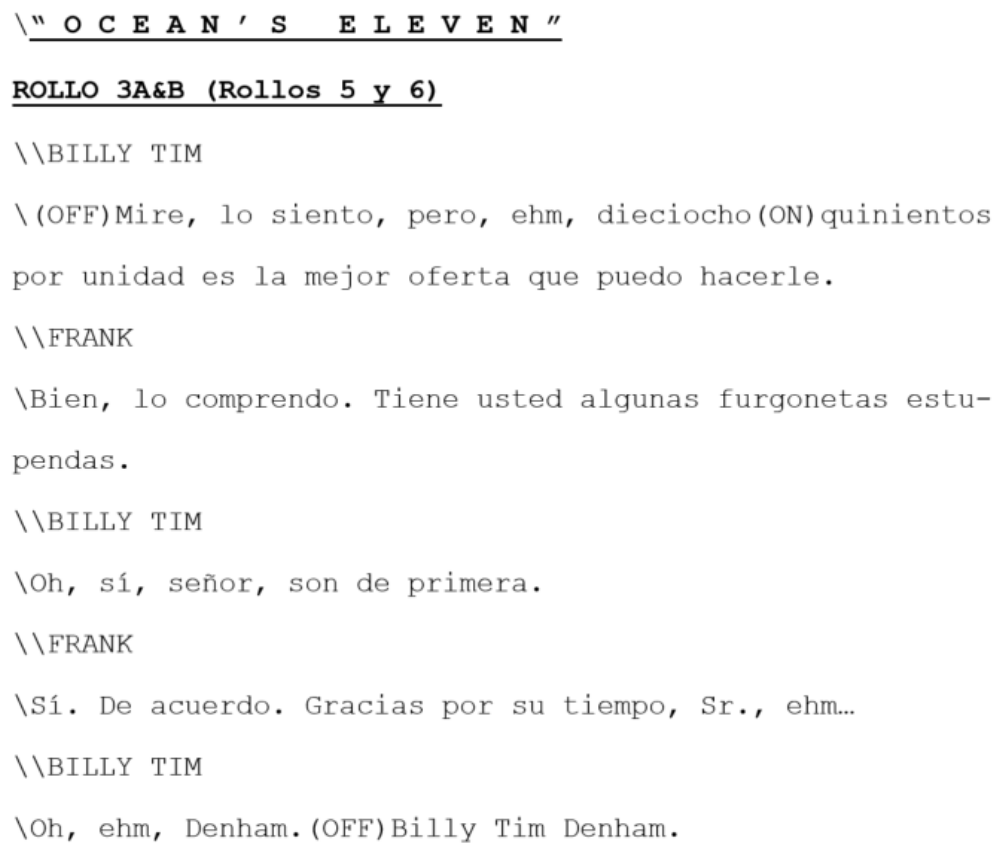

Figure 2. Layout and formatting of the translated version of a sample from Ocean's Eleven Scene 12 (Rovira-Beleta, 2001)

As shown in Figure 2, the translation includes some dubbing symbols even though this task is supposed to be undertaken by dialogue writers or dubbing assistants. When asked about this, Rovira-Beleta ${ }^{3}$ confirmed that translators tend to include some but not all dubbing symbols, such as those referring to paralinguistic gestures and overlapping 
dialogue, with pauses being indicated often by suspension dots (and not by the standard symbol /). In the scene analysed, the symbols included are used to indicate if the actors' voices are on screen or not (ON and $\mathrm{OFF})$, if there are interruptions and overlapping utterances $(\mathrm{P})$, and if relevant paralinguistic information will have to be recreated by dubbing actors (R, RIENDO or RISITA for laughter, and G for generic sounds articulated by the phonatory system). Example 1 shows some of the symbols included in the translated version in context, exactly as they appear in this working document:

\section{Example 1}

\begin{tabular}{|l|l|l|}
\hline Original version & Translated version & Back translation \\
\hline $\begin{array}{l}\text { FRANK: I tried all sorts of } \\
\text { brand and lotion. I even } \\
\text { went fragrant free for a } \\
\text { whole year. Now, my sister, } \\
\text { she uses er-er-er- er-er, aloe } \\
\text { vera with a little sunscreen } \\
\text { in it, yeah. }\end{array}$ & $\begin{array}{l}\text { FRANK: Yo he probado toda } \\
\text { clase de lociones.(O: cremas.) } \\
\text { Incluso estuve un año entero } \\
\text { usando las no perfumadas. Pero } \\
\text { mi hermana usa, ehm...ehm, ehm, } \\
\text { ehm, ehm, áloe vera con un poco } \\
\text { de protector(OFF)solar. Sí. }\end{array}$ & $\begin{array}{l}\text { FRANK: I have tried all sorts of } \\
\text { lotions (Option: creams). I even } \\
\text { used fragrant free ones for a } \\
\text { whole year. But my sister uses, } \\
\text { er...er, er, er, er, aloe vera with a } \\
\text { bit of sun(off screen)screen. Yes. }\end{array}$ \\
$\begin{array}{l}\text { BILLY TIM: Ah. } \\
\text { BILLY TIM: (OFF)(P)Ah. Mm. }\end{array}$ & $\begin{array}{l}\text { BILLY TIM: (Off screen) } \\
\text { (interrupts previous utterance)Ah. } \\
\text { Mm. }\end{array}$ \\
$\begin{array}{l}\text { FRANK: And ideally } \\
\text { speaking, we all should wear } \\
\text { gloves when going to bed } \\
\text { but I found out that er... it } \\
\begin{array}{l}\text { would be a little interference } \\
\text { in my social agenda, you } \\
\text { know what I mean. }\end{array}\end{array}$ & $\begin{array}{l}\text { FRANK: (OFF)(P)Aunque lo } \\
\text { ideal sería que todos(ON)nos } \\
\text { pusiéramos guantes para ir a la } \\
\text { cama. Pero he descubierto que eso } \\
\text { interferiría un poco en mi vida } \\
\text { social(O: en mis relaciones), } \\
\text { usted ya me entiende.(RISITA) }\end{array}$ & $\begin{array}{l}\text { FRANK: (Off screen)(interrupts } \\
\text { previous utterance) Although it } \\
\text { would be ideal if we all (on } \\
\text { screen) wore gloves to go to bed. } \\
\text { But I have found out that it would } \\
\text { interfere a bit in my social life } \\
\text { (Option: in my relations), you } \\
\text { know what I mean (laughter). }\end{array}$ \\
\hline
\end{tabular}

It is interesting to note that, although hesitations are commonly conveyed through the symbol (G) or (Gs) when several occur in succession (Torralba Miralles, 2016, p. 62) and although the symbol $(\mathrm{G})$ is used elsewhere in this working document, in this example they have been verbalised instead, thus revealing some inconsistencies in the application of these symbols.

Another revealing aspect of this example is the inclusion of alternative solutions in brackets, preceded by the letter $\mathrm{O}$ (which stands for option). Rovira-Beleta suggests 
translating 'lotions' as lociones, but provides also cremas (creams) as an option.

Likewise, he translates 'social agenda' as vida social, including relaciones as an alternative. This is an instance of the dialogic mechanisms used by translators to communicate with dialogue writers, and highlights the 'unfinished' nature of the translated version (De los Reyes Lozano, 2016, p. 159) or its status as a "proto-text, [...] full of different alternatives and linguistic solutions from which a future [dubbing] agent will choose the most appropriate one" (Richart-Marset, 2009, p. 150, my translation). These examples also indicate that while the reasons for including alternatives can be linguistic in nature, the translator is already mindful of the synchronisation process to which his translation will be subject to, and anticipates the need to use shorter alternatives (cremas instead of lociones), for instance.

Although the sample investigated is short, the analysis has further revealed that in addition to providing alternative options, the translator also used notes to communicate with the dialogue writer, as evidenced in Example 2.

Example 2

\begin{tabular}{|c|c|c|}
\hline Original version & Translated version & Back translation \\
\hline $\begin{array}{l}\text { FRANK: Yeah, ok, thank } \\
\text { you for your time Mr, er... }\end{array}$ & $\begin{array}{l}\text { FRANK: Sí. De acuerdo. Gracias } \\
\text { por su tiempo, Sr., ehm... }\end{array}$ & $\begin{array}{l}\text { FRANK: Yes, all right. Thank } \\
\text { you for your time, Mr., er... }\end{array}$ \\
\hline $\begin{array}{l}\text { BILLY TIM: Well, Denham. } \\
\text { Billy Tim Denham. }\end{array}$ & $\begin{array}{l}\text { BILLY TIM: Oh, ehm, Denham. } \\
\text { (OFF)Billy Tim Denham. }\end{array}$ & $\begin{array}{l}\text { BILLY TIM: Oh, er..., Denham. } \\
\text { (Off screen) Billy Tim Denham. }\end{array}$ \\
\hline \multirow[t]{2}{*}{$\begin{array}{l}\text { FRANK: Yes, Denim like a } \\
\text { jean. }\end{array}$} & $\begin{array}{l}\text { FRANK: Sí, como la tela } \\
\text { vaquera*. }\end{array}$ & $\begin{array}{l}\text { FRANK: Yes, like the jeans } \\
\text { material*. }\end{array}$ \\
\hline & $\begin{array}{l}\text { NOTA: "Denham" se pronuncia } \\
\text { como "denim", nombre que se da } \\
\text { a la tela vaquera entre fabricantes } \\
\text { de ropa, incluso en España. Ver, } \\
\text { por ejemplo, } \\
\text { http://www.amichi.es/ } \\
\text { n_tendencias5.htm, o } \\
\text { http://www.solomoda.com/ } \\
\text { tendencias/68/index.shtml }\end{array}$ & $\begin{array}{l}\text { NOTE: "Denham" is pronounced } \\
\text { like "denim", which is the name } \\
\text { given by clothes manufacturers, } \\
\text { even in Spain, to the material } \\
\text { used for jeans. See, for instance, } \\
\text { http://www.amichi.es/ } \\
\text { n_tendencias5.htm or } \\
\text { http://www.solomoda.com/ } \\
\text { tendencias/68/index.shtml }\end{array}$ \\
\hline
\end{tabular}


As De los Reyes Lozano (2016, p. 158) contends, translator's notes do not only function as a communicative device between translator and dialogue writer: they also allow translators to justify their solutions. In this case Rovira-Beleta's note supports his decision to use the term denim in Spanish to render a case of phonological wordplay.

The discussion so far has illustrated how the translated version complies with or disregards existing conventions of layout and presentation, as well as how the additional information included reflects its status as a working document. The next section investigates how the dialogue writer transforms this information in the synchronised version.

\subsubsection{Analysis of changes in the synchronised version}

One of the few changes in the synchronised version relates to its layout and division into takes. In line with the norms identified by Marzà (2016, p. 58) when surveying dubbing studios in Spain, the text for Scene 12 has been divided into six takes of approximately 7-8 lines on average, with no more than 5 lines per take for the same character. The first take of the scene analysed is shown in Figure 3 by way of example.

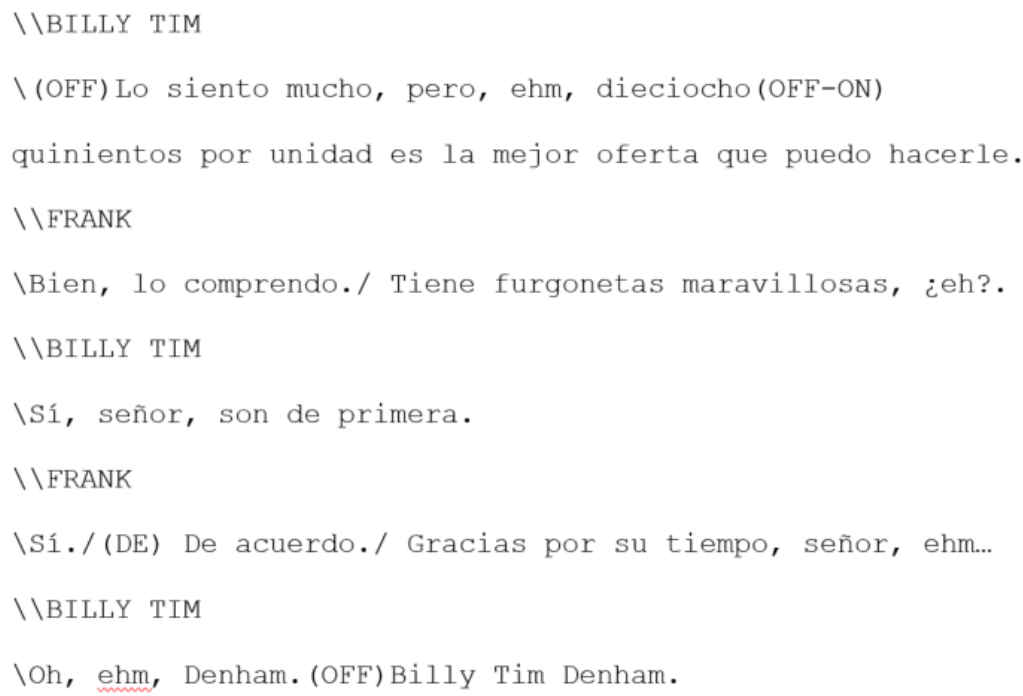


Figure 3. Synchronised version: layout, formatting and division into takes (Abril, 2001)

As Figure 3 shows, no time codes have been included, and the format does not follow standard formatting conventions (Marzà, 2016, p. 54), with dialogues being included underneath character names instead of to their right.

Comparison of the information in Figure 2 and Figure 3 reveals the type of changes implemented in the dialogue writing process. In addition to inserting relevant symbols (e.g. the pause symbol / in Frank's utterances, or the symbol (DE) indicating that Frank is with his back to the camera (de espaldas) while uttering most of the last sentence in this take), the dialogue writer has on occasion substituted existing ones with more accurate alternatives. On the first line in Figure 3, Abril has used (OFF-ON) instead of the symbol $(\mathrm{ON})$ to indicate the travelling movement of the camera while Billy Tim pronounces 'apiece' in the original, and quinientos in the dubbed version.

Figures 2 and 3 further point to a significant shift. Frank's utterance 'They are some great looking vans that you got out there', translated initially as Tiene usted algunas furgonetas estupendas (You have some great vans), turns to Tiene furgonetas maravillosas, ¿eh? (You have wonderful vans, huh?) in the synchronised version. The change reveals an attempt both to shorten the translation to comply with isochrony in a fast-paced dialogue, and to reinforce the naturalness of the translated dialogue (with the addition of the phatic discourse marker, ¿eh?). Changes targeted at achieving a more colloquial and natural-sounding dialogue are pertinent considering that the original sentence uttered by Frank mirrors spontaneous conversation in English, and that his speech, diastratically marked in the source text, is subjected to standardisation in the Spanish dubbing. These examples attest to the usefulness of working documents or archival information of the dubbing process to understand how problematic aspects, 
such as register and characterisation, have been dealt with in the dubbing of this scene into Spanish.

A quantitative analysis of the changes implemented in the synchronised version is provided in Table 1 to shed light on the role of the dialogue writer, albeit on the basis of what is a very short sample. It draws on the classification of strategies to account for these changes proposed by Matamala (2010), which has been modified as follows:

- Addition: new information not included in the translated version is introduced.

- Modification (reduction): the utterance is modified and the text is made shorter.

- Modification (amplification): the utterance is modified and the text is made longer.

- Omission: information included in the translated version has been omitted.

- Substitution: the length of the utterance is kept the same, but some parts of the utterance have been substituted by others.

\begin{tabular}{|l|c|c|}
\hline Change implemented & $\begin{array}{l}\text { Number of changes } \\
\text { (including dubbing } \\
\text { symbols) }\end{array}$ & $\begin{array}{l}\text { Number of changes } \\
\text { (excluding dubbing } \\
\text { symbols) }\end{array}$ \\
\hline Addition & 30 & 2 \\
\hline Modification (amplification) & 9 & 10 \\
\hline Modification (reduction) & 14 & 14 \\
\hline Omission & 13 & 9 \\
\hline Substitution & 17 & 8 \\
\hline Total & $\mathbf{8 3}$ & $\mathbf{4 3}$ \\
\hline
\end{tabular}

Table 1. Quantitative analysis of changes implemented in the synchronised version.

Rovira-Beleta included some dubbing symbols in the translated version and the changes introduced in this regard have also been quantified. This is why the category of addition is particularly high, as 28 of the changes observed refer to the addition of dubbing 
symbols by the dialogue writer (e.g. as in the case of the symbol (DE) above). However, considering that this is normally the task of the dialogue writer and not of the translator, the focus should be on the second column of Table 1, which excludes dubbing symbols to avoid skewed results, and provides an overview of the type of changes introduced in the actual translation (43 in total). The analysis shows that the majority of the changes tend towards text reduction with 23 cases in total: 14 cases of modification-reduction and 9 of omission. Changes tending towards amplification are next with 12 occurrences (comprising addition and modification-amplification), followed by 8 cases entailing substitution. This finding is in line with previous studies (Matamala, 2010) and foregrounds the idea of dialogue writing as a creative process that involves constant tweaking and the implementation of different strategies, considering the synchronies at play in dubbing and the interaction between text and image at all times. Example 3 illustrates the implementation of all strategies in a short excerpt from the film, with the exception of omission, in order to show the transformation the translated version undergoes.

Example 3

\begin{tabular}{|c|c|c|c|c|}
\hline & Original version & Translated version & Synchronised version & Change implemented \\
\hline $3 a$ & $\begin{array}{l}\text { FRANK: Man, } \\
\text { you've got some } \\
\text { lovely hands here. }\end{array}$ & $\begin{array}{l}\text { FRANK: Vaya, tiene } \\
\text { unas manos preciosas. } \\
\text { [Wow, you have } \\
\text { beautiful hands.] }\end{array}$ & $\begin{array}{l}\text { FRANK: (DE) Tiene } \\
\text { usted unas manos } \\
\text { preciosas. } \\
\text { [(DE) You have beautiful } \\
\text { hands.] }\end{array}$ & $\begin{array}{l}\text { Addition (DE) } \\
\text { Substitution } \\
\text { (vaya> usted) }\end{array}$ \\
\hline $3 b$ & $\begin{array}{l}\text { FRANK: Do you } \\
\text { moisturize? }\end{array}$ & $\begin{array}{l}\text { FRANK: ¿Usa crema } \\
\text { hidratante? } \\
\text { [Do you use moisturising } \\
\text { cream?] }\end{array}$ & $\begin{array}{l}\text { FRANK: }(\mathbf{A}) \text { ¿Usa crema } \\
\text { hidratante? } \\
\text { [(A) Do you use } \\
\text { moisturising cream?] }\end{array}$ & $\begin{array}{l}\text { Addition (A) - this } \\
\text { symbol indicates that the } \\
\text { dubbing actor needs to } \\
\text { start earlier than the } \\
\text { original to make sure } \\
\text { isochrony is complied } \\
\text { with. }\end{array}$ \\
\hline $3 c$ & $\begin{array}{l}\text { BILLY TIM: I am } \\
\text { sorry? }\end{array}$ & $\begin{array}{l}\text { BILLY TIM: ¿Cómo } \\
\text { dice? } \\
\text { [What did you say?] }\end{array}$ & $\begin{array}{l}\text { BILLY TIM: ¿Perdón? } \\
\text { [Sorry?] }\end{array}$ & Modification - reduction \\
\hline $3 d$ & $\begin{array}{l}\text { FRANK: I tried all } \\
\text { sorts of brand and } \\
\text { lotion. }\end{array}$ & $\begin{array}{l}\text { FRANK: Yo he probado } \\
\text { toda clase de lociones. } \\
\text { (O: cremas.) }\end{array}$ & $\begin{array}{l}\text { FRANK: Yo me he dado } \\
\text { toda clase de lociones. } \\
\text { [I have applied all sorts of } \\
\text { lotions] }\end{array}$ & $\begin{array}{l}\text { Substitution (he } \\
\text { probado>me he dado) }\end{array}$ \\
\hline
\end{tabular}




\begin{tabular}{|c|c|c|c|c|}
\hline & & $\begin{array}{l}\text { [I have tried all sorts of } \\
\text { lotions (Option: creams)] }\end{array}$ & & \\
\hline $3 e$ & $\begin{array}{l}\text { FRANK: I even } \\
\text { went fragrant free } \\
\text { for a whole year }\end{array}$ & $\begin{array}{l}\text { FRANK: Incluso estuve } \\
\text { un año entero usando las } \\
\text { no perfumadas. } \\
\text { [I even used fragrant free } \\
\text { ones for a whole year.] }\end{array}$ & $\begin{array}{l}\text { FRANK: Y durante un año } \\
\text { me di unas que no tienen } \\
\text { alcohol. } \\
\text { [And for one year I applied } \\
\text { ones without alcohol.] }\end{array}$ & $\begin{array}{l}\text { Modification - reduction } \\
\text { (incluso estuve un año } \\
\text { entero > y durante un } \\
\text { año) } \\
\text { Modification - } \\
\text { amplification (usando las } \\
\text { no perfumadas > me di } \\
\text { unas que no tienen } \\
\text { alcohol) }\end{array}$ \\
\hline $3 f$ & $\begin{array}{l}\text { FRANK: Now, my } \\
\text { sister, she uses er- } \\
\text { er-er-er-er, aloe } \\
\text { vera with a little } \\
\text { sunscreen in it, } \\
\text { yeah. }\end{array}$ & $\begin{array}{l}\text { FRANK: Pero mi } \\
\text { hermana usa, ehm...ehm, } \\
\text { ehm, ehm, ehm, áloe } \\
\text { vera con un poco de } \\
\text { protector(OFF)solar. Sí. } \\
\text { [But my sister uses, er... } \\
\text { er, er, er, aloe vera with a } \\
\text { bit of sun(OFF)screen. } \\
\text { Yeah.] }\end{array}$ & $\begin{array}{l}\text { FRANK: Pero mi hermana } \\
\text { utiliza, ah,/ ah ah ah áloe } \\
\text { vera/ con un poco de(DE- } \\
\text { FP) protector solar. Sí. } \\
\text { [But my sister uses, ah... } \\
\text { ah, ah, ah, aloe vera / with } \\
\text { a bit of (DE-FP)sunscreen. } \\
\text { Yeah.] }\end{array}$ & $\begin{array}{l}\text { Addition (usa }>\text { utiliza) } \\
\text { Substitution (ehm }>\text { ah) } \\
\text { Substitution }(\mathrm{OFF}>\mathrm{DE}- \\
\text { FP) } \\
\text { Addition (pause symbol } \\
\text { /) }\end{array}$ \\
\hline
\end{tabular}

Example 3 sheds light onto the potential reasons motivating these changes. Whereas some are clearly motivated by synchrony constraints (e.g. in 3c, 3e or 3f), in other cases changes seem to reflect preferences from the dialogue writer, especially where characters are not on screen and/or the change does not alter substantially the number of syllables or the presence of bilabial or labiodental consonants (e.g. substitution in $3 \mathrm{a}$ or 3d). Nevertheless, as shown in Table 2, most changes are motivated by synchrony constraints (30 out of 43 if we consider both isochrony and lip synchrony), a finding that is also in line with previous genetic analysis of dubbed versions.

\begin{tabular}{|l|c|c|c|c|c|c|}
\hline $\begin{array}{l}\text { Change } \\
\text { implemented }\end{array}$ & Isochrony & Preference & $\begin{array}{l}\text { Lip } \\
\text { synchrony }\end{array}$ & Standardisation & Naturalness/Orality & Total \\
\hline Addition & 1 & 0 & 0 & 0 & 1 & 2 \\
\hline Omission & 6 & 0 & 0 & 3 & 0 & 9 \\
\hline Substitution & 0 & 5 & 3 & 0 & 0 & 8 \\
\hline $\begin{array}{l}\text { Modification } \\
\text { (reduction) }\end{array}$ & 12 & 1 & 1 & 0 & 0 & 14 \\
\hline $\begin{array}{l}\text { Modification } \\
\text { (amplification) }\end{array}$ & 4 & 3 & 3 & 0 & 0 & 10 \\
\hline Total & 23 & 9 & 7 & 3 & 1 & 43 \\
\hline
\end{tabular}


Table 2. Quantitative analysis of possible motivations behind the changes implemented in the synchronised version ${ }^{4}$.

Although further investigations are needed, the data and the examples above suggest that lip synchrony is not as restrictive as we have been led to believe by the dubbing industry, at least in the type of shots analysed in this scene. Indeed, the analysis undertaken here shows that target language renderings only match the original roughly, and certainly without having to make sure that the translation includes exactly the same number of bilabials or fricative consonants, even when the character is clearly on screen and on a relevant type of shot (e.g. medium/close shot). This is reflected in example $3 \mathrm{e}$ above, but also in other renderings within this scene (e.g. They are some great looking vans that you got out there > Tiene furgonetas maravillosas, ¿eh?).

As regards the alternatives provided by Rovira-Beleta, discussed in the previous section, the preferred translator's options were adopted in the synchronised version, with the exception of the translation of my 'social agenda', where Abril opted for the translator's alternative (mis relaciones). In line with the findings of Desilla in this volume, this illustrates a change on the implicitness/explicitness continuum. It also reveals the usefulness of alternatives in the dubbing process, and suggests that the translation is much more polished and final than the term 'rough translation' seems to suggest, even if it is still deemed a working document. This is an aspect to be further investigated, as the polished nature of this particular case study could be due to RoviraBeleta's extensive experience in the dubbing industry, both as a translator and dialogue writer.

A final point worth discussing regards the inclusion of non-standard dubbing symbols in the synchronised version. This is the case of (FP), illustrated in example $3 \mathrm{f}$ above, a symbol which is not included in the extensive descriptive overview provided 
by Torralba Miralles (2016). As corroborated by Gonzalo Abril, this is an ad-hoc symbol which he uses regularly in his role as dialogue writer to indicate that although a character is on screen, lip synchrony is not relevant. FP stands for Fuera de Plano (out of shot) and could be deemed an equivalent of the more widespread SB (Sin Boca; without mouth), used to indicate that the character's mouth is not visible. The use of this symbol in this scene is particularly relevant as it is used where non-verbal information (e.g. the image) contradicts or complements verbal information. Throughout this scene there are several close-up shots of the handshake between Frank and Billy Tim that reveal information not conveyed verbally, that is, the coercion used by Frank to convince Billy Tim to lower the price of the vans. Although there is no way to ascertain this, it could be argued that, in addition to suggesting the non-relevance of lip synchrony, the inclusion of the symbol (FP) invites dubbing actors to shift their focus to the image and to deliver their lines accordingly.

\subsection{From synchronised version to final recorded version: shifts and further decision-making}

The analysis has revealed that the changes to the synchronysed version implemented during the actual recording were minimal, with only 12 identified. This finding is not surprising, as the dialogue writer and dubbing director were the same person. Yet, the nature and motivation behind those changes reveals the fascinating dynamics of the dubbing process. For instance, it is remarkable that some of the solutions originally suggested by the translator and discarded by the dialogue writer were recouped in the final recording, as shown in example 4a.

Example 4 


\begin{tabular}{|c|c|c|c|c|}
\hline & Original version & Translated version & Synchronised version & Final version \\
\hline $4 a$ & $\begin{array}{l}\text { FRANK: I even } \\
\text { went fragrant free } \\
\text { for a whole year. }\end{array}$ & $\begin{array}{l}\text { FRANK: Incluso estuve } \\
\text { un año entero usando las } \\
\text { no perfumadas. } \\
\text { [I even used fragrant free } \\
\text { ones for a whole year.] }\end{array}$ & $\begin{array}{l}\text { FRANK: Y durante un año } \\
\text { me di unas que no tienen } \\
\text { alcohol. } \\
\text { [And for one year I applied } \\
\text { ones without alcohol.] }\end{array}$ & $\begin{array}{l}\text { FRANK: Y durante un } \\
\text { año me di unas no } \\
\text { perfumadas. } \\
\text { [And for one year I } \\
\text { applied ones without } \\
\text { fragrance.] }\end{array}$ \\
\hline $4 b$ & $\begin{array}{l}\text { FRANK: }[\ldots] \text { but I } \\
\text { found out that er... } \\
\text { it would be a little } \\
\text { interference in my } \\
\text { social agenda, you } \\
\text { know what I mean. }\end{array}$ & $\begin{array}{l}\text { FRANK: [...] Pero he } \\
\text { descubierto que eso } \\
\text { interferiría un poco en mi } \\
\text { vida social(O: en mis } \\
\text { relaciones), usted ya me } \\
\text { entiende.(RISITA) } \\
\text { [But I have found out } \\
\text { that it would interfere a } \\
\text { bit in my social life } \\
\text { (Option: in my relations), } \\
\text { you know what I mean } \\
\text { (laughter)] }\end{array}$ & $\begin{array}{l}\text { FRANK: [...] Pero he } \\
\text { descubierto que eso } \\
\text { interferiría un poco en mis/ } \\
\text { relaciones, usted ya me } \\
\text { entiende. (RIE) } \\
\text { [But I have found out that } \\
\text { it would interfere a bit in } \\
\text { my relations, you know } \\
\text { what I mean (laughs)] }\end{array}$ & $\begin{array}{l}\text { FRANK: Pero he } \\
\text { descubierto que eso } \\
\text { interferiría un poco en mi } \\
\text { agenda social, usted ya } \\
\text { me entiende. (RIE) } \\
\text { [But I have found out } \\
\text { that it would interfere a } \\
\text { bit in my social agenda, } \\
\text { you know what I mean } \\
\text { (laughs)] }\end{array}$ \\
\hline
\end{tabular}

In some cases, however, the final solution keeps only part of the translated version, as shown in 4b, where agenda social (social agenda; as in the original) is used as a final solution instead of vida social (social life).

The most striking change implemented during this last stage is reflected in Example 5, where the solution originally provided by Rovira-Beleta for the wordplay discussed above (Denham and denim), which he substantiated with a footnote, was altered. Billy Tim's surname is changed completely to introduce a reference to the US culture (Davy Crockett), which could be deemed as rather obscure to the target audience.

\section{Example 5}

\begin{tabular}{|l|l|l|l|}
\hline \multicolumn{1}{|c|}{ Original version } & Translated version & Synchronised version & Final version \\
\hline FRANK: Yeah, ok, & FRANK: Sí. De acuerdo. & FRANK: (DE) De & FRANK: De acuerdo. \\
thank you for your & Gracias por su tiempo, & acuerdo./ Gracias por su & Gracias por su tiempo, \\
time, Mr, er... & Sr., ehm... & tiempo, señor, ehm... & señor, ehm... \\
BILLY TIM: & BILLY TIM: Oh, ehm, & BILLY TIM: Oh, ehm, & BILLY TIM: Oh, eh... \\
Well, Denham. & Denham.(OFF)Billy Tim & Denham.(OFF)Billy Tim & Crockett. Billy Tim \\
Billy Tim Denham. & Denham. & Denham. & Crockett. \\
FRANK: & FRANK: Sí, como la tela & FRANK: (FP) Sí, como la & FRANK: Ah, como el \\
Yes, Denim like a & vaquera. & tela vaquera. & trampero. \\
jean. & & & \\
\hline
\end{tabular}




\begin{tabular}{|l|l|l|l|}
\hline & $\begin{array}{l}\text { [FRANK: Yes. All right. } \\
\text { Thank you for your time, } \\
\text { Mr., er... }\end{array}$ & $\begin{array}{l}\text { [FRANK: (DE) All right. / } \\
\text { Thank you for your time, } \\
\text { Mister, er... }\end{array}$ & $\begin{array}{l}\text { [FRANK: All right. } \\
\text { Thank you for your time, } \\
\text { Mister, er... }\end{array}$ \\
& $\begin{array}{l}\text { Denham. (OFF) Billy } \\
\text { Tim Denham. }\end{array}$ & $\begin{array}{l}\text { BILLY TIM: Oh, er..., } \\
\text { Denham. (OFF) Billy Tim }\end{array}$ & $\begin{array}{l}\text { BILLY TIM: Oh, er..., } \\
\text { Crockett. Billy Tim }\end{array}$ \\
& $\begin{array}{l}\text { Denham. } \\
\text { FRANK: Yes, like the } \\
\text { jeans material.] }\end{array}$ & $\begin{array}{l}\text { FRANK: (FP) Yes, like } \\
\text { the jeans material.] }\end{array}$ & $\begin{array}{l}\text { FRANK: Oh, like the } \\
\text { trapper.] }\end{array}$ \\
\end{tabular}

Abril revealed that this change was agreed with the supervisor appointed by the producer during the revision process and implemented before the recording. As for the motivation, although he could not recall the reason precisely, he considered that the culture-specific reference was probably deemed more meaningful and easier to process for the target audience than the phonological shift (Denham>denim). His input and its impact on the analysis underscores the usefulness of establishing contact with the agents in the dubbing process in addition to studying archival material, and the contribution of other dubbing agents to the final text.

\section{Final remarks}

This genetic analysis of Ocean's Eleven Scene 12 has shed light on the creative process involved in its dubbing, as well as on the dubbing conventions used throughout. Whereas most are in line with standard practices in the Spanish dubbing industry (e.g. division of the text into takes), there are also discrepancies (the insertion of symbols by the translator or the use of the ad-hoc symbol FP by the dialogue writer). Paradoxically, such discrepancies are likewise inherent to the work of dubbing agents themselves, and characteristic of the Spanish dubbing industry (Cerezo Merchán et al., 2016).

In line with the findings of existing studies, the analysis has revealed that the changes introduced during the different dubbing phases tend towards text reduction and 
condensation, and are mainly motivated by synchronisation (principally by isochrony). It has also shown that the dialogue writer resorts to various strategies to synchronise the text submitted by the translator, and that some of the changes implemented seem to result from individual preferences. In this particular case, changes implemented were more frequent at the dialogue writing stage than at the final recording stage, and emphasise the role of other agents such as the dubbing supervisor.

One of the goals of this paper has been to underline the potential of archival material in AVT in general and dubbing in particular. It has also underscored the usefulness of contacting the dubbing agents directly to reconstruct the dubbing process fully. Drawing complementarily on these sources, the analysis has underlined the collaborative nature of dubbing and the status of all the professionals involved as coauthors in their own right. As Paulínyová's (2016) study contended, the qualitative analysis has suggested that the working document provided by translators is not as 'rough' as we are led to believe, inasmuch as they are already considering the synchronisation process to which their translation will be later subject to. Their translation is subject to constant transformations by other dubbing agents, yet they have several dialogic mechanisms at their disposal to defend and justify their translation solutions.

Input from the translator and dialogue writer of the sample analysed here further demonstrates that there can be fluid and constant cooperation between them throughout the whole process. Determining whether the level of collaboration existing in the sample analysed is an exception or the norm was not the aim of this paper, but is of relevance given that the descriptions of workflows available in the existing literature (Chaume, 2012, p. 31; Martínez, 2004) portray dubbing as a result of collective agency, but not so much as a dynamic and truly collaborative task, where agents work together 
towards a final product. As illustrated in Figure 4, representations of dubbing workflows would benefit from a more dynamic approach contemplating real collaboration and feedback mechanisms throughout, and including also viewers, who already use existing communication channels in some contexts (e.g. social media) to express their satisfaction or discontent with a particular dubbed version.

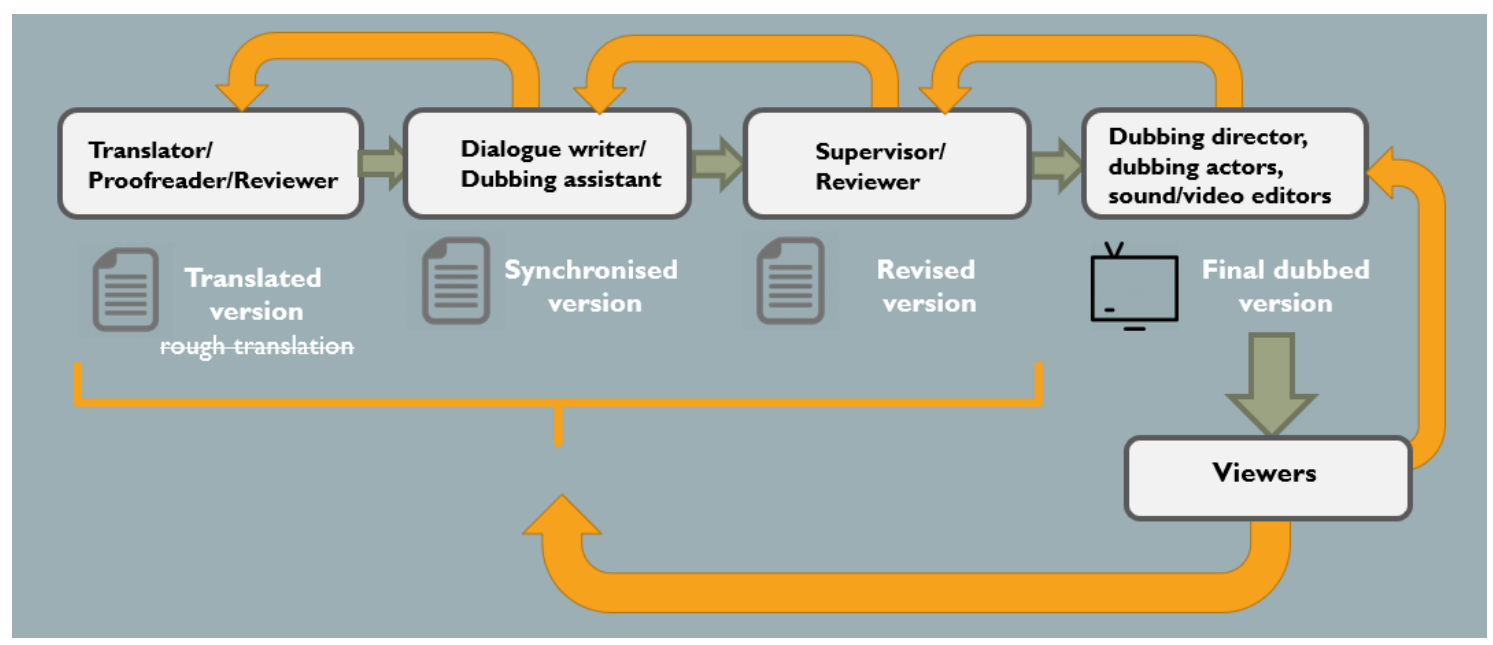

Figure 4. Example of collaborative dubbing workflow

Establishing this kind of collaborative mechanisms and workflows should not be complicated given recent technological developments such as cloud-dubbing platforms. A case in point is ZOO Dubs, developed by ZOO Digital (https://www.zoodigital.com/), aimed at automating time-consuming tasks and promoting collaboration amongst all the agents involved in the dubbing process, making sure they can work remotely. The latter is essential in what Chaume (2019, p. 112) has termed "collaborative dubbing", whereby professionals working from different locations contribute to the production and recording of a single dubbed version. In my view, while these developments are paramount for the easy and fluid implementation of collaborative workflows, they are not mutually inclusive. Collective agency and remote dubbing can be realised without true collaboration, and the latter is only possible if suitable communication channels are established between all professionals and, ideally, if their roles as co-creators are 
recognised appropriately, both from the point of view of resources (e.g. fees paid and time allocated to each task) and acknowledgement.

\section{Acknowledgements}

The author would like to thank Quico Rovira-Beleta and Gonzalo Abril for their generosity in sharing their time and the working documents analysed in this paper.

\section{Endnotes}

1. Translators are not even mentioned in the article from The New York Times, which thus implies that the quality of dubbed versions is mainly in the hands of dubbing actors and the dubbing director. This has been a common approach whenever dubbing is broached in Spanish media. For example, no reference to the role of translators was made when the work of dubbing directors was addressed in the documentary series Los oficios de la cultura, which is broadcast by the Spanish National Television RTVE (available from http://www.rtve.es/alacarta/videos/los-oficios-de-la-cultura/oficios-cultura-directordoblaje-juan-luis-rovira/1451393/).

2. Quico Rovira-Beleta (Ocean's Eleven's translator) and Gonzalo Abril (Ocean's Eleven's dialogue writer and dubbing director), email messages to author, on $13^{\text {th }}$ and $15^{\text {th }}$ March 2019.

3. Quico Rovira-Beleta (Ocean's Eleven's translator) email message to author, on $13^{\text {th }}$ March 2019.

4. The data included in this table does not take into consideration the changes affecting dubbing symbols. Being motivated by synchrony in all cases, including them in the quantification would have skewed the results.

\section{References}

Cadena Ser (2019). Dani Solé es el traductor al español de la mejor comedia de los Emmy 2019, 23 September 2019. Retrieved 23 November 2019, from https://cadenaser.com/programa/2019/09/23/la_ventana/1569256634_955481.html

Cerezo Merchán, B., Chaume, F., Granell, X., Martí Ferriol, J. L., Martínez Sierra, J. J., Marzà, A., \& Torralba Miralles, G. (Eds.) (2016). La traducción para el doblaje en España: Mapa de convenciones. Castelló de la Plana: Universitat Jaume I.

Chaume, F. (2012). Audiovisual Translation: Dubbing. Manchester: St. Jerome. 
Chaume, F. (2019). Audiovisual translation in the age of digital transformation: Industrial and social implications. In I. Ranzato and S. Zanotti (Eds.), Reassessing Dubbing: Historical Approaches and Current Trends. Amsterdam/Philadelphia: John Benjamins.

De los Reyes Lozano, J. (2016). Genética del doblaje cinematográfico. La versión del traductor como proto-texto en el filme Rio. Linguistica Antverpiensia, 14, 149-167.

Díaz-Cintas, J. (2018). Film censorship in Franco's Spain: the transforming power of dubbing. Perspectives, 27(2), 1-19.

Eldoblaje.com. (2019). Ocean's Eleven (Hagan juego) - Ficha eldoblaje.com. Retrieved 15 March 2019, from http://www.eldoblaje.com/datos/FichaPelicula.asp?id=1193

Goldsmith, J. (2019). Netflix Wants to Make Its Dubbed Foreign Shows Less Dubby. The New York Times, 19 July 2019. Retrieved 23 November 2019, from https://www.nytimes.com/2019/07/19/arts/television/netflix-money-heist.html.

Martínez, X. (2004). Film dubbing: Its process and translation. In P. Orero (ed.), Topics in Audiovisual Translation (pp. 3-8). Amsterdam/Philadelphia: John Benjamins.

Marzà, A. (2016). Los takes del doblaje. In B. Cerezo Merchán, F. Chaume, X. Granell, J. L. Martí Ferriol, J. J. Martínez Sierra, A. Marzà, \& G. Torralba Miralles (Eds.), La traducción para el doblaje en España: Mapa de convenciones (pp. 37-59). Castelló de la Plana: Universitat Jaume I.

Matamala, A. (2010). Translations for dubbing as dynamic texts: Strategies in film synchronisation. Babel, 56(2), 101-118.

Mereu Keating, C. (2016). 'The Italian color': Race, crime iconography and dubbing conventions in the Italian-language versions of Scarface (1932). Altre Modernità, Special Issue, 107-123.

Minutella, V. (2015). 'It ain't ogre til it's ogre': The dubbing of Shrek into Italian. In J. Díaz Cintas \& J. Neves (Eds.), Audiovisual Translation: Taking Stock (pp. 140-158). Newcastle upon Tyne: Cambridge Scholars Publishing.

Munday, J. (2013). The role of archival and manuscript research in the investigation of translator decision-making. Target, 25(1), 125-139.

Paulínyová, L. (2016). The dubbing process in numbers: Who changes translation the most? In E. Pérez \& M. Kazimír (Eds.), Audiovisual Translation: Dubbing and Subtitling in the Central European Context (pp. 11-22). Nitra: Constantine the Philosopher University.

Richart-Marset, M. (2009). La alegría de transformar: Teorías de la traducción y teoría del doblaje audiovisual. Valencia: Tirant lo Blanch. 
Richart-Marset, M. (2013). La caja negra y el mal de archivo: defensa de un análisis genético del doblaje cinematográfico. Trans: Revista de Traductología, 17, 51-69.

Spiteri Miggiani, G. (2019). Dialogue Writing for Dubbing. An Insider's Perspective. Cham: Palgrave Macmillan.

Torralba Miralles, G. (2016). Los símbolos en la traducción para el doblaje. In B. Cerezo Merchán, F. Chaume, X. Granell, J. L. Martí Ferriol, J. J. Martínez Sierra, A. Marzà, \& G. Torralba Miralles (Eds.), La traducción para el doblaje en España: Mapa de convenciones (pp. 61-75). Castelló de la Plana: Universitat Jaume I.

Whitman-Linsen, C. (1992). Through the Dubbing Glass: The Synchronization of American Motion Pictures into German, French, and Spanish. Frankfurt: Peter Lang.

Zanotti, S. (2014). Translation and transcreation in the dubbing process. A genetic approach. Cultus, 7, 107-132.

\section{Filmography}

Los oficios de la cultura. Dirección de doblaje. Juan Luis Rovira. (2012). RTVE.

Ocean's Eleven (2001). Dir. Steven Soderbergh.

Rio (2011). Dir. Carlos Saldanha.

Shrek (2001). Dir. Andrew Adamson \& Vicky Jenson

Young Frankenstein (1974). Dir. Mel Brooks. 